\title{
Perancangan Aplikasi Berbasis Android untuk Pemeriksaan Pengecatan Kapal Bangunan Baru
}

\author{
Dandy Adrianto dan Triwilaswandio Wuruk Pribadi \\ Departemen Teknik Perkapalan, Fakultas Teknologi Kelautan, Institut Teknologi Sepuluh Nopember (ITS) \\ Jl. Arief Rahman Hakim, Surabaya 60111 Indonesia \\ e-mail: triwilas.its@gmail.com
}

\begin{abstract}
Abstrak- Proses pemeriksaan pengecatan kapal yang ada saat ini dilakukan secara manual dimana coating inspector dan pihak terkait lainnya yang melakukan pemeriksaan mengacu pada form pemeriksaan yang telah disetujui. Penginputan dan pelaporan hasil pemeriksaan dilakukan dengan menggunakan kertas yang ditulis secara manual sehingga tidak efektif dan terdapat resiko besar jika terjadi kehilangan dokumen karena tidak memiliki backup. Selain itu, proses pemeriksaan cat yang dilakukan kurang efektif dikarenakan antar pihak terkait yang melakukan pemeriksaan tidak memiliki pengetahuan dan pengalaman yang sama. Tujuan dari pengerjaan Studi ini adalah untuk merancang aplikasi berbasis android yang berfungsi sebagai sarana untuk memudahkan praktisi di lapangan dalam proses pemeriksaan dan dokumentasi pemeriksaan pengecatan kapal. Dalam pengerjaan Studi ini, pertama dilakukan observasi pada kegiatan pemeriksaan pengecatan kapal bangunan baru yang dilakukan oleh coating inspector di lapangan. Kemudian yang kedua adalah studi literatur tentang lingkup pekerjaan dari coating inspector, standart pemeriksaan dari tahap perisapan hingga final, dan standart untuk melaporkan hasil pemeriksaan cat. Setelah itu dilakukan perancangan aplikasi. Perancangan aplikasi dilakukan dengan pembuatan kerangka dasar aplikasi, diagram alir data dan entitas, mock up aplikasi, perancangan database, dan pengkodingan aplikasi yang dirancang. Pada aplikasi yang dirancang dapat dilakukan penginputan hasil pemeriksaan pada form pemeriksaan yang didalamnya terdapat batasan pemeriksaan yang telah ditentukan, review hasil pemeriksaan, penyimpanan hasil pemeriksaan dalam bentuk file, dan fitur search dokumen hasil pemeriksaan dan dokumen lain yang terkait. Uji coba aplikasi dilakukan kepada responden yang merupakan praktisi di lapangan yang melakukan pemeriksaan pengecatan kapal bangunan baru. Dari hasil pengujian kuisoner yang diperoleh dapat ditarik kesimpulan bahwa aplikasi yang dirancang perlu diaplikasikan sebagai sarana pendukung proses pemeriksaan pengecatan kapal bangunan baru.
\end{abstract}

Kata Kunci- Aplikasi Android, Pengecatan Kapal, Pemeriksaan Pengecatan Kapal, Coating inspector.

\section{PENDAHULUAN}

$\mathrm{D}$ ALAM proses pembangunan kapal baru tidak terkecuali reparasi kapal terdapat pekerjaan coating di dalamnya. Coating merupakan tahapan yang harus dilalui pada proses pembangunan kapal. Tahapan ini harus dilakukan dengan benar karena penerapan coating yang salah berpengaruh pada umur cat dan biaya operasional kapal tersebut. Pekerjaan reparasi (repair work) sering terjadi pada setiap instalasi coating baru. Untuk menghindari coating failure dibutuhkan pengetahuan literatur mengenai standart-standart yang harus dilakukan. Aspek pengalaman juga berperan penting dalam hal ini, oleh karena itu seorang inspector harus memiliki pengetahuan literatur yang baik diimbangi dengan pengalaman yang banyak pula. Hal tersebut yang menjadi permasalahan junior coating inspector.

Tugas dari coating inspector belum selesai hingga dokumentasi proyek dan laporan (report) dikirimkan ke pihak owner dan direview oleh klas [1]. Dalam prosesnya, pembuatan laporan membutuhkan waktu yang relatif lama untuk penyelesaiannya karena berkas yang dibutuhkan tidak sedikit selain itu proses dokumentasi dan pelaporan dilakukan secara manual sehingga ada resiko terjadinya kehilangan laporan yang akan menghambat produktifitas dari proses pembangunan kapal tersebut.

Oleh karena itu dibutuhkan aplikasi berbasis android yang dapat digunakan untuk memberikan panduan pekerjaan inspeksi yang harus dilakukan meliputi surface preparation, mixing dan thinning, dan proses inspeksi lainnya sehingga diharapkan seorang coating inspector dapat bekerja sesuai standard dan menghindari adanya repair work akibat proses aplikasi yang salah. Dengan aplikasi ini seorang coating inspector dapat lebih mudah dalam melakukan penyusunan laporan karena di dalam aplikasi ini terdapat form standard yang dapat disisipi dengan keterangan atau gambar disertai standardnya sesuai inspeksi yang telah dilakukan dan dapat dikirimkan langsung melalui koneksi internet pada pihak owner, shipyard, klas dan pihak terkait lainnya.

\section{STUDI PUSTAKA}

\section{A. Pengecatan Kapal Bangunan Baru}

Pengecatan kapal bangunan baru dimulai dari material datang hingga kapal selesai dilakukan erection. Pengecatan kapal ini berguna untuk melindungi kulit kapal dari proses pengkaratan dan juga binatang laut, karena hampir semua material penyusun kapal adalah logam (pelat baja) dan daerah kerja kapal adalah di laut maka sifat logam (pelat baja) reaktif terhadap korosi. Sebelum melakukan pengerjaan pengecatan terlebih dahulu material yang akan dicat harus bersih dari kotoran-kotoran minyak maupun sisa-sisa cat dan debu. Gambar 1 menunjukkan urutan proses pengecatan kapal bangunan baru. 


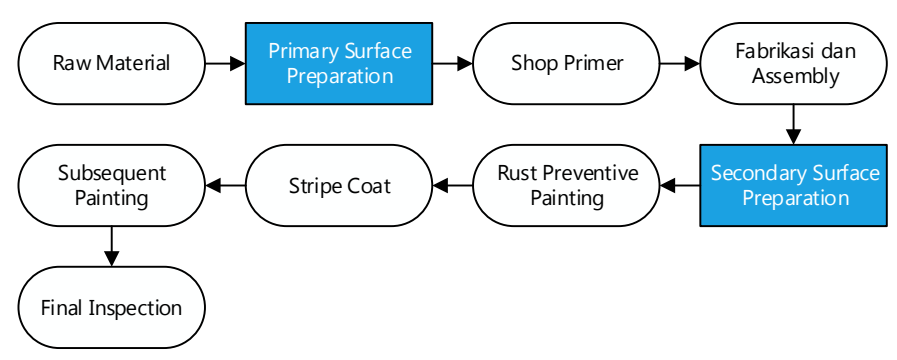

Gambar 1. Urutan proses pengecatan kapal

\section{B. Surface Preparation}

Surface preparation ini merupakan proses untuk menghilangkan semua kotoran dari permukaan material yang dapat mengganggu daya rekat coating atau dapat membuat coating mudah terkelupas. Selain menghilangkan kotoran, surface preparation juga berfungsi untuk menghilangkan karat, mill scale, surface defect seperti sisa pengelasan dan permukaan yang tajam yang dapat menyebabkan coating rusak [2].

Tabel 1.

Item pemeriksaan pre-surface preparation

\begin{tabular}{ll}
\hline \hline Nama Proses & Item Pemeriksaan \\
\hline Steel Surface & Inspeksi Visual: \\
Preparation (Pre- & - Shrap edges \\
Surface Preparation) & - Miss weld \\
& - Weld defect \\
& - Imperfect steel \\
& surface \\
\hline \hline
\end{tabular}

Pada Tabel 1 dijelaskan item-item yang dilakukan pemeriksaan pada tahap pre-surface preparation [3]. Metodemetode surface preparation yang umum digunakan adalah solvent cleaning, abrasive blasting, waterjetting, hand tool cleaning, power tool cleaning, dan lain-lain. Pada Tabel 2 dijelaskan item-item pemeriksaan pada proses surface preparation [3].

Tabel 2.

Item pemeriksaan surface preparation

\begin{tabular}{ll}
\hline \hline Nama Proses & Item Pemeriksaan \\
\hline Surface Preparation & Kondisi Lingkungan: \\
(Blasting dan Power & - Cek relative humidity \\
Tool) & - Cek dew point \\
& - Cek temperatur \\
& material \\
& Kontaminan \\
& Cleanliness grade \\
& Surface Profile \\
& Cek Dust level \\
& Cek Soluble Salt \\
\hline \hline
\end{tabular}

\section{Pengecatan Kapal}

Pengecatan kapal pada block stage umumnya dilakukan indoor dan kondisi lingkungan yang terkontrol [4]. Metode yang digunakan sesuai dengan spesifikasi kontrak yang disetujui. Metode pengecatan kapal dapat dilakukan dengan airless spray, roller, brush, dan conventional air spray. Pada Tabel 3 dijelaskan item-item pemeriksaan pengecatan kapal [3].
Tabel 3.

Item pemeriksaan pengecatan kapal

\begin{tabular}{ll}
\hline \hline Nama Proses & Item Pemeriksaan \\
\hline Painting & Inspeksi Visual \\
& Dry Film thickness (DFT) \\
& Measurement \\
& Cleanliness dan Curing \\
& Time Tiap Coating \\
Holiday detection \\
\hline \hline
\end{tabular}

\section{Coating Inspector}

Coating Inspector memiliki tanggung jawab yang bervariasi dalam setiap pekerjaan. Peranan inspector adalah sebagai quality control technician yang memiliki tanggung jawab untuk melakukan observasi dan report tentang aspek teknis dari proyek coating dan untuk mengecek kesesuaian atau tidaknya project dari project specification [1]. Coating Inspector harus dapat menjamin bahwa project specification telah dilakukan dengan benar sesuai dengan yang dibuat. Selain itu, Coating Inspector harus mendokumentasikan hasil pemeriksaan.

\section{E. Aplikasi Android}

Android merupakan system operasi berbasis Linux yang bersifat terbuka (open source) dan dirancang untuk perangkat seluler layar sentu seperti smartphone dan computer tablet [5]. Aplikasi Android dikembangkan dalam bahasa pemrograman Java dengan menggunakan kit pengembangan perangkat lunak Android (SDK). SDK ini terdiri dari seperangkat perkakas pengembangan, termasuk debugger, perpustakaan perangkat lunak, emulator handset yang berbasis QEMU, dokumentasi, kode sampel, dan tutorial. Didukung secara resmi oleh lingkungan pengembangan terpadu (IDE) Eclipse, yang menggunakan plugin Android Development Tools (ADT)

\section{METODOLOGI PENELITIAN}

\section{A. Studi Literature}

Studi literatur yang dilakukan untuk mengerjakan studi ini terdiri dari:

1) Mempelajari item-item pekerjaan inspeksi yang dilakukan oleh coating inspector pada pembangunan kapal bangunan baru.

2) Alur inspeksi coating inspector.

3) Mempelajari standard yang mengatur kegiatan inspeksi coating inspector.

4) Mempelajari proses dokumentasi dan report hasil inspeksi yang sesuai standard.

5) Mempelajari pengantar sistem informasi mengenai sistem database dan MySQL.

6) Mempelajari sistem aplikasi android.

\section{B. Studi Lapangan}

Studi lapangan dilakukan di galangan PT. Lamongan Marine Industry. Berikut merupakan studi lapangan yang dilakukan:

1) Mengidentifikasi item pemeriksaan pengecatan kapal 
bangunan baru.

2) Mengidentifikasi alur proses inspeksi pengecatan kapal bangunan baru.

3) Mempelajari form dan dokumen laporan inspeksi.

\section{Pengumpulan Data}

Tahapan ini adalah pengumpulan data yang menunjang dalam penulisan studi ini yang terdiri dari:

1) List pekerjaan pemeriksaan coating inspector pada pembangunan kapal baru.

2) Standard yang mengatur kegiatan coating inspector untuk kapal bangunan baru.

3) Form laporan dan dokumentasi hasil inspeksi coating inspector.

\section{Pengolahan Data}

Berikut merupakan tahap pengolahan data yang dilakukan

1) Melakukan pengelompokkan data pekerjaan pemeriksaan.

2) Melakukan pembuatan list pekerjaan yang harus dilakukan.

3) Pembuatan list panduan untuk pemeriksaan.

4) Pembuatan struktur laporan.

\section{E. Perancangan Aplikasi Android}

Tahap perancangan aplikasi ini antara lain:

1) Perancangan permodelan aplikasi

Pembuatan entitiy relationship diagram, data flow diagram, dan system interface diagram.

2) Perancangan aplikasi

Berikut merupakan proses perancangan aplikasi yang dilakukan:

a. Pembuatan mock up aplikasi.

b. Perancangan interface atau tampilan antarmuka aplikasi.

c. Perancangan database pemeriksaan pengecatan kapal bangunan baru.

d. Pengcodingan aplikasi.

3) Pengujian Aplikasi

a. Uji coba aplikasi pada praktisi di lapangan

b. Uji kepuasan dalam penggunaan program dengan kuisoner

c. Uji perbandingan kinerja aplikasi dengan sistem eksisting.

\section{SISTEM PEMERIKSAAN PENGECATAN KAPAL BANGUNAN BARU}

\section{A. Pemeriksaan Pengecatan Kapal Bangunan Baru}

Proses pengecatan kapal perlu adanya pengawasan dari coating inspector yang bertujuan untuk menjamin proyek kapal yang dibangun dapat sesuai dengan kualitas dan standard yang diinginkan. Untuk pembagian aktifitas pekerjaan pemeriksaan pengecatan, sebelumnya tiga pihak (three parties) yang terdiri dari owner, galangan dan manufaktur coating telah menentukan perjanjian atau persetujuan apa saja yang harus dilakukan inspeksi (inspection agreement) yang terdapat pada persetujuan tiga pihak (tripartite agreement). Setelah persetujuan dilakukan barulah kemudian inspeksi pengecatan kapal dapat dilaksanakan.

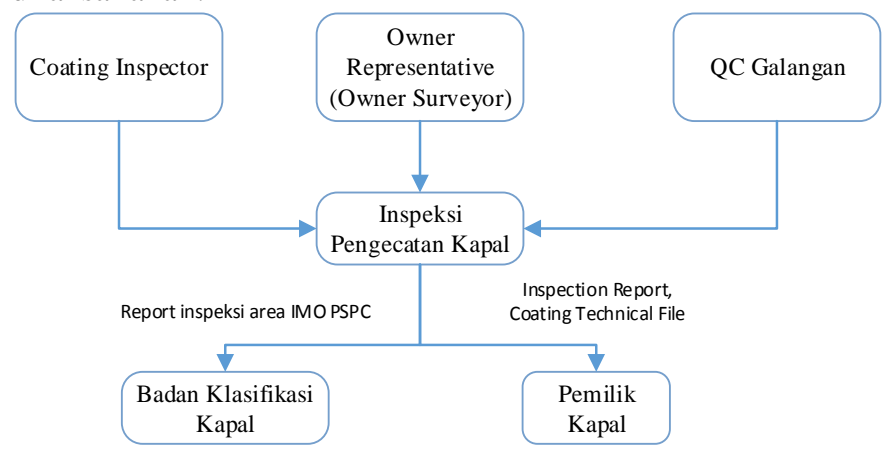

Gambar 2. Alur proses pemeriksaan dan pelaporan hasil pemeriksaan

Pada Gambar 2 dijelaskan inspeksi pengecatan kapal dilakukan oleh tiga pihak yaitu Coating inspector, Owner, dan QC Galangan. Pekerjaan inspeksi yang dilakukan sesuai dengan inspection agreement pada tripartie agreement. Coating inspector bertanggung jawab untuk melakukan pelaporan hasil inspeksi pada area yang diatur IMO PSPC kepada badan klasifikasi kapal. Sedangkan QC Galangan memiliki tugas untuk melakukan pelaporan hasil inspeksi harian (daily inspection report) dan pembuatan Coating Technical File kepada pemilik kapal. Owner surveyor juga ditugaskan untuk melakukan pemeriksaan jika diperlukan dan merupakan salah satu pihak yang melakukan approval atau submit laporan inspeksi. Proses pemeriksaan pengecatan kapal bangunan baru dapat dilihat pada Tabel 4 dibawah ini.

Tabel 4

pemeriksaan pengecatan kapal bangunan baru

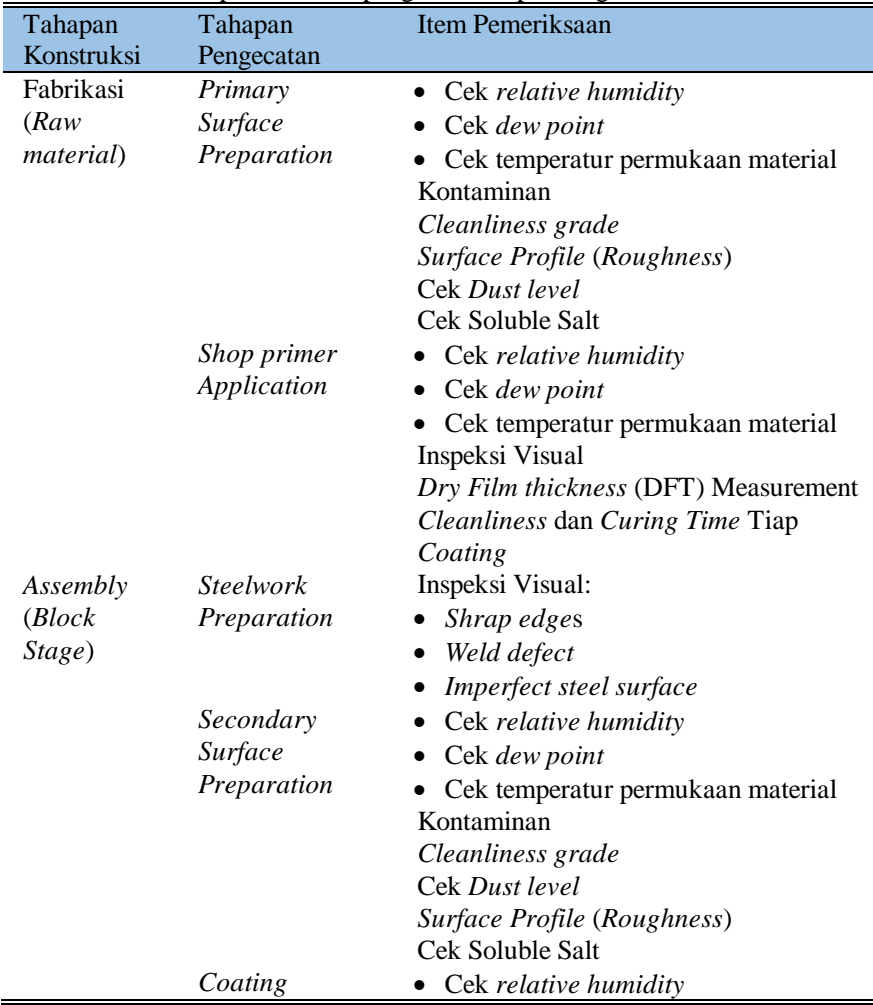




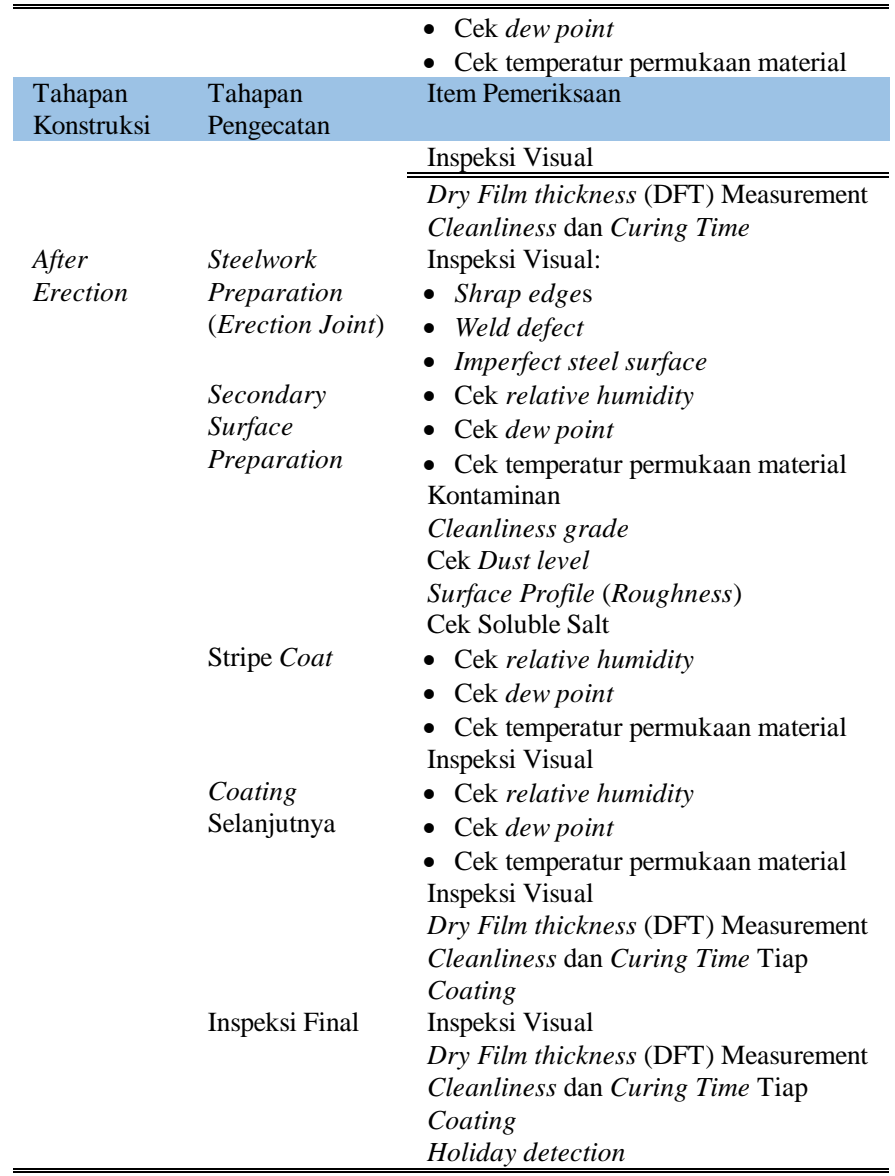

\section{B. Form Pemeriksaan}

Form pemeriksaan merupakan form yang telah disetujui oleh tiga pihak sebagai acuan inspektor untuk melakukan pekerjaannya.

COATING LOG (STEEL SURFACE PREPARATION)

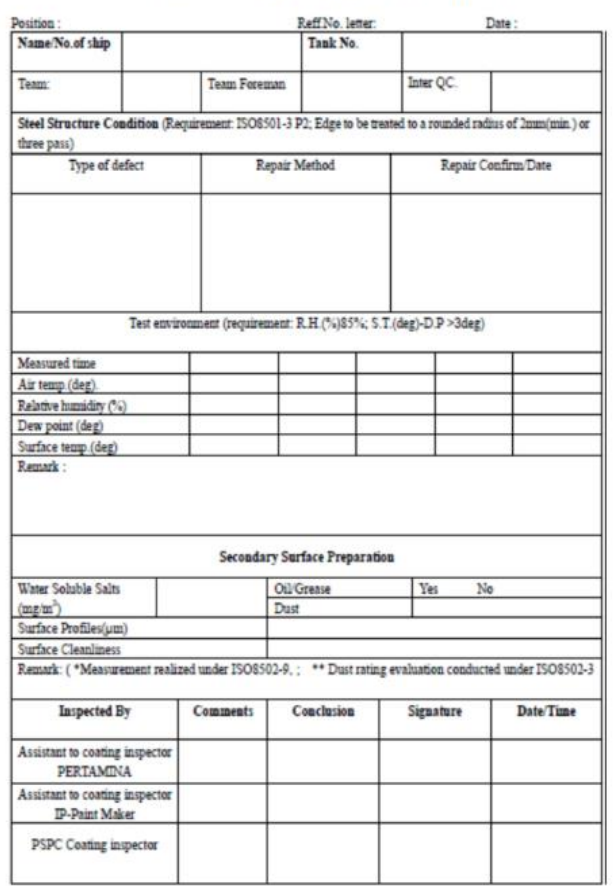

Gambar 3. Contoh form pemeriksaan pada proses surface preparation
Gambar 3 diatas merupakan contoh format form pemeriksaan yang telah disetujui oleh owner, shipyard, dan coating inspector. Setiap proyek memiliki form pemeriksaan yang berbeda-beda sehingga perlu dilakukan persetujuan sebelum proyek pengecatan kapal dimulai. Form pemeriksaan yang telah diisi harus dilaporkan ke pihak-pihak terkait untuk dilakukan persetujuan/approval dan disimpan untuk keperluan Coating Technical File (CTF) kapal yang dibangun.

\section{Kendala Pemeriksaan Pengecatan Kapal Bangunan Baru Saat Ini}

Setelah dilakukan studi lapangan dan interview kepada praktisi di lapangan, kendala yang sering dihadapi adalah kurang praktisnya proses dokumentasi inspeksi dan pelaporan hasil inspeksi. Pembuatan form inspeksi dan input data masih dilakukan secara manual sehingga jika terjadi kehilangan coating inspector tidak memiliki backup data inspeksi dan harus melakukan input ulang data inspeksi. Selain itu, proses pelaporan kepada pihak terkait seperti pemilik kapal dan klas tidak dapat dilakukan secara langsung sehingga kurang praktis.

\section{PERANCANGAN APLIKASI ANDROID}

\section{A. Penjelasan Umum Aplikasi Android}

Aplikasi yang dirancang memiliki 2 fungsi login yaitu administrator dan user. Fungsi login administrator adalah melakukan input item komponen/blok/area yang hendak dilakukan inspeksi, memberikan standard parameter inspeksi, memberikan file panduan inspeksi dan mengakses laporan hasil inspeksi. Sedangkan login user yang pada hal ini dioperasikan oleh coating inspector dan pihak terkait lainnya yang hendak melakukan pemeriksaan dan pengawasan pengecatan kapal bangunan baru memiliki fungsi untuk melakukan pengisian form pemeriksaan yang telah dirancang dan sesuai dengan proses inspeksi yang telah dipilih oleh administrator. Setelah melakukan pengisian form pemeriksaan, user dapat melakukan persetujuan form inspeksi dan melihat hasil report yang telah jadi berdasarkan pengisian form pemeriksaan yang telah dilakukan. Untuk satu proyek kapal yang didaftarkan oleh administrator, dapat memiliki maksimal 4 orang user yang dapat melakukan pengisian form pemeriksaan. User tersebut sebelumnya didaftarkan oleh administrator dengan menyantumkan Nomer Induk Karyawan (NIK) sebagai verifikasinya.

\section{B. Perancangan Aplikasi Android}

Perancangan aplikasi dilakukan dengan tiga program utama yaitu Android Studio, MySQL, dan phpMyAdmin. Android Studio digunakan untuk merancang aplikasi sesuai dengan permintaan desainer. Sedangkan MySQL digunakan untuk merancang database aplikasi yang dirancang. Sebelum program tersebut digunakan, sebelumnya desainer memberikan diagram alir dan mockup aplikasi. Diagramdiagram yang dibutuhkan antara lain Entitiy Relationship Diagram, Data flow Diagram, dan System Interface Diagram. 
Setelah diagram selesai dibuat, implementasikan DFD dan SID pada program Android Studio. Kemudian implementasikan ERD pada database MySQL dengan tools phpMyAdmin. Setelah itu, aplikasi android dan database dihubungkan secara online dengan file php.

\section{Simulasi Aplikasi Android}

1) Administrator

Administrator merupakan salah satu entitas dari aplikasi ini yang memiliki kewenangan untuk mendaftarkan proyek, memanajemen pengguna aplikasi, memasukkan file bantuan, menginput blok/area yang akan diperiksa, dan pemilihan proses pengecatan disertai dengan pengisian parameter pada setiap form pemeriksaan proses pengecatan yang dipilih,

\begin{tabular}{|c|c|c|c|}
\hline \multicolumn{3}{|c|}{ 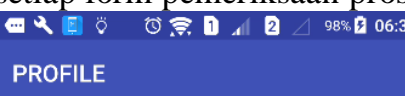 } & 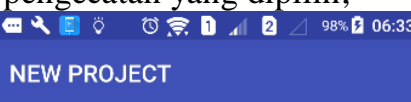 \\
\hline \multirow[b]{2}{*}{14} & \multirow[b]{2}{*}{ Tugboat Intan Megah } & dandy 94 & \multirow[t]{2}{*}{ Owner } \\
\hline & & - & \\
\hline \multirow[t]{6}{*}{16} & oil tanker 1 & - & Nama Proyek \\
\hline & & & Panjang Kapal \\
\hline & & & Lebar Kapal \\
\hline & & & Tinggi Kapal \\
\hline & & & Muatan Kapal \\
\hline & LOGOUT & TAMBAH PROYEK & Sarat Kapal \\
\hline & (a) & & (b) \\
\hline
\end{tabular}

Gambar 4 (a) merupakan tampilan dari menu awal setelah administrator melakukan $\log$ in. Pada halaman menu ini, administrator dapat mendaftarkan proyek kapal yang akan dilakukan pemeriksaan cat. Setelah melakukan pemilihan menu tambah proyek akan muncul tampilan pengisian data kapal seperti Gambar 4 (b) diatas. Selain data kapal, administrator juga mendaftarkan user yang memiliki dengan cara memasukkan NIK user ke data proyek tersebut.

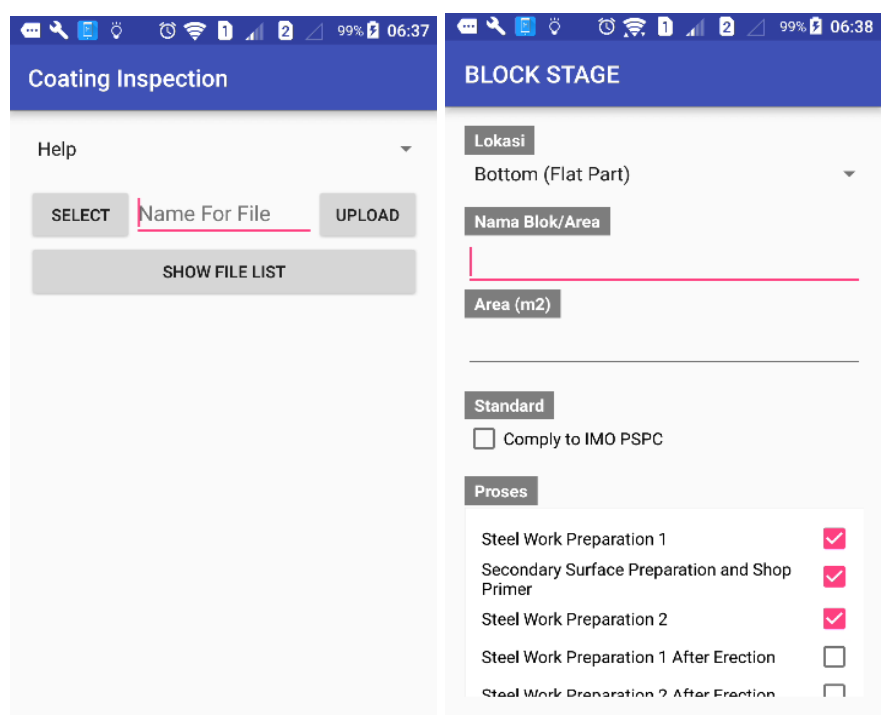

(a)

(b)

Gambar 5. Menu input file panduan (a) dan halaman input data blok

Gambar 5 (a) merupakan menu penginputan file bantuan untuk user yang nantinya dimaksudkan untuk dapat membantu user dalam proses pemeriksaan. Sedangkan pada Gambar 5 (b) merupakan form pengisian data blok yang akan dilakukan pemeriksaan dan juga pemilihan proses pemeriksaan yang akan dilakukan pada blok. Setelah blok terdaftar, selanjutnya administrator memberikan batasan atau parameter pada setiap form pemeriksaan yang telah dipilih.

2) User

User pada aplikasi ini adalah coating inspector, qc shipyard, owner surveyor, dan klas. Kegiatan yang dilakukan oleh user adalah memiliki kapal yang akan dilakukan pemeriksaan, mengisi form pemeriksaan pada blok /area yang telah diinput sebelumnya oleh administrator, dan mendokumentasikan proses pemeriksaan yang telah

dilakukan.

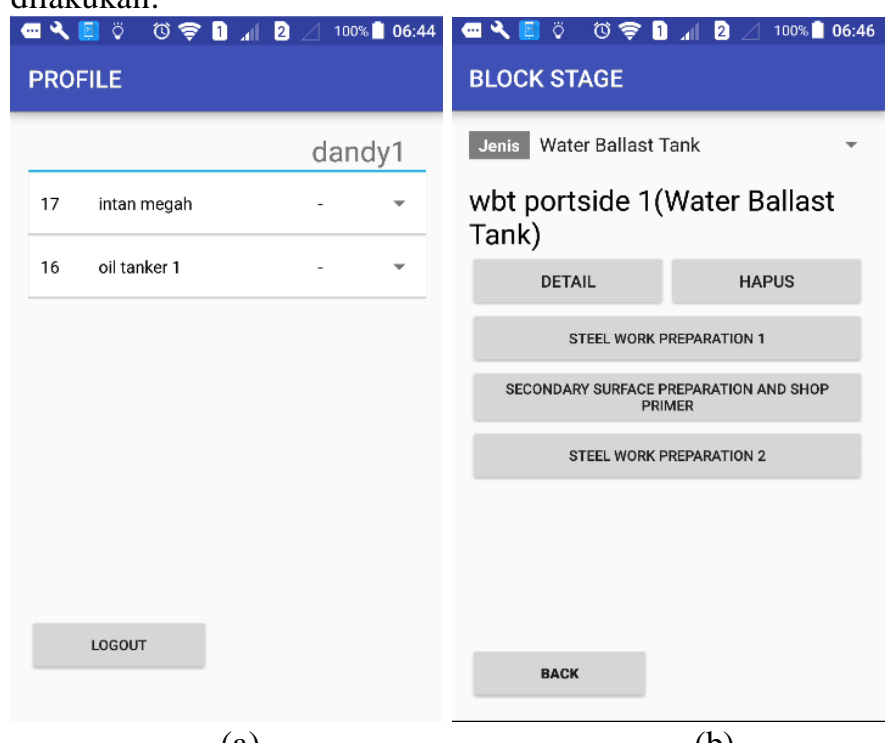

(a)

(b)

Gambar 6. Menu pilih proyek (a) dan halaman list blok (b)

Gambar 6 (a) merupakan menu awal aplikasi yang pada menu ini user dapat melakukan pemilihan proyek kapal yang akan dilakukan pemeriksaan. Setelah dilakukan pemilihan 
proyek kapal, selanjutnya dipilih komponen yang akan di inspeksi dan akan muncul halaman seperti pada Gambar 6 (b). Kemudian user memilih proses pemeriksaan yang akan dilakukan.
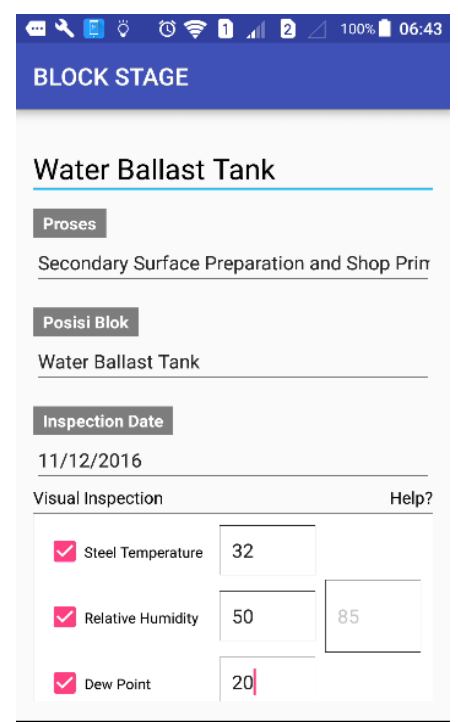

Gambar 7. Halaman pengisian form pemeriksaan

Gambar 7 merupakan contoh tampilan form pemeriksaan yang telah dipilih. Pada form ini terdapat parameter pemeriksaan yang sebelumnya diinput oleh administrator sehingga dapat menjadi panduan inspektor dalam pengambilan keputusan.

\section{ANALISIS DAN UJI COBA APLIKASI}

\section{A. Analisis Sistem}

Analisis sistem dilakukan dari hasil interview dan komentar praktisi di lapangan setelah dilakukan pengujian aplikasi. Berikut hasil perbandingan sistem ditunjukkan pada Tabel 5 di bawah ini.

Tabel 5.

Analisis perbandingan kelebihan dan kekurangan sistem

\begin{tabular}{|c|c|c|}
\hline Aspek & Sistem Eksisting & Aplikasi \\
\hline Koneksi & Tanpa Koneksi & $\begin{array}{l}\text { Menggunakan koneksi } \\
\text { internet (selalu online) }\end{array}$ \\
\hline $\begin{array}{l}\text { Penulisan } \\
\text { form } \\
\text { inspeksi }\end{array}$ & $\begin{array}{l}\text { Penulisan form inspeksi } \\
\text { dilakukan secara manual dan } \\
\text { format form pemeriksaan } \\
\text { setiap proyek berbeda-beda }\end{array}$ & $\begin{array}{l}\text { Melakukan checklist dan } \\
\text { penulisan secara cepat karena } \\
\text { form pemeriksaan telah } \\
\text { didesain sesuai standard }\end{array}$ \\
\hline Penyusunan & Jika ditemukan & Pada aplikasi terdapat fitur \\
\hline laporan dan & ketidaksesuaian harus di foto & upload file gambar yang \\
\hline dokumentasi & terlebih dahulu & dapat dimasukkan secara \\
\hline hasil & mengirimkannya ke laptop & langsung ke dalam laporan \\
\hline inspeksi & untuk diinput pada laporan & sehingga lebih efektif \\
\hline $\begin{array}{l}\text { Proses } \\
\text { pelaporan }\end{array}$ & $\begin{array}{l}\text { Proses pelaporan lama } \\
\text { (memindahkan data tertulis ke } \\
\text { komputer terlebih dahulu baru } \\
\text { dilaporkan) }\end{array}$ & $\begin{array}{l}\text { Proses pelaporan lebih } \\
\text { ringkas dan cepat (setelah } \\
\text { laporan inspeksi di submit, } \\
\text { dapat dibuka oleh user lain } \\
\text { yang terintegrasi) }\end{array}$ \\
\hline SDM & $\begin{array}{l}\text { Diperlukan seseorang yang } \\
\text { memiliki pengetahuan dan } \\
\text { pengalaman yang memadai } \\
\text { seperti senior coating inspector }\end{array}$ & $\begin{array}{l}\text { Terdapat fitur bantuan yang } \\
\text { berisikan panduan dan } \\
\text { standard pemeriksaan yang } \\
\text { dapat membantu proses } \\
\text { pengawasan }\end{array}$ \\
\hline Keamanan & $\begin{array}{l}\text { Penyimpanan laporan terdapat } \\
\text { pada lemari penyimpanan dan } \\
\text { laporan pengawasan ada } \\
\text { kemungkinan hilang/rusak }\end{array}$ & $\begin{array}{l}\text { Penyimpanan laporan } \\
\text { terdapat pada database server } \\
\text { dan dapat dibackup di HP } \\
\text { dengan fitur save report pada }\end{array}$ \\
\hline
\end{tabular}

aplikasi.

Dari Tabel 5 diatas dapat dilihat perbandingan antara sistem eksisting dengan sistem aplikasi yang dirancang. Pada tabel tersebut terdapat kelebihan maupun kekurangan dari sistem eksisting dan sistem aplikasi.

\section{B. Uji Coba Aplikasi}

Untuk mengetahui kelayakan aplikasi, dilakukan uji coba aplikasi terlebih dahulu kepada praktisi di lapangan yang masih memiliki keterkaitan dalam pemeriksaan pengecatan kapal bangunan baru. Setelah dilakukan uji coba, selanjutnya pengujian dilakukan dengan memberikan kuisoner untuk mengetahui respon praktisi mengenai aplikasi yang dirancang dan penilaian dari kuisoner ini akan digunakan sebagai acuan kelayakan aplikasi.

\section{KESIMPULAN/RINGKASAN}

Kesimpulan yang didapatkan dari pengerjaan studi ini antara lain:

1) Pemeriksaan pengecatan kapal bangunan baru yang ada saat ini memiliki beberapa kelemahan diantaranya memerlukan coating inspector yang memiliki pengalaman dan pengetahuan yang memadai untuk melakukan pemeriksaan dengan benar, form pemeriksaan dibuat secara manual sehingga setiap proyek memiliki form yang berbeda-beda, proses penyusunan laporan dan pelaporan hasil pemeriksaan dilakukan secara manual sehingga kurang efektif.

2) Aplikasi android yang dirancang memiliki kelebihan yang diantaranya terdapat file panduan pemeriksaan yang berisikan prosedur pemeriksaan sesuai standard ISO, ASTM, dan IMO PSPC, form pemeriksaan yang disusun sesuai IMO PSPC dan observasi di PT. Lamongan Marine Industry, fitur penyampaian laporan yang terintegrasi antara pihak-pihak terkait, dan data history pemeriksaan sebelumnya yang telah dilakukan yang dapat digunakan sebagai acuan pemeriksaan selanjutnya.

3) Uji coba aplikasi ini dilakukan kepada praktisi di lapangan seperti coating inspector, quality control painting galangan, dan owner surveyor. Dalam pengujian kelayakan aplikasi ini digunakan data kuisoner. Dari hasil kuisoner yang telah dilakukan pengolahan data, didapati nilai kelayakan sebesar 29,4 dari nilai maksimum 35 yang mengartikan bahwa aplikasi yang dirancang layak untuk diaplikasikan di lapangan sebagai sarana pendukung proses pemeriksaan pengecatan kapal bangunan baru.

\section{DAFTAR PUSTAKA}

[1] NACE. (2011). Coating inspector Program Level 1. Houston: NACE International.

[2] Berendsen, A. M. (1989). Marine Painting Manual. Netherlands: Kluwer Academic Publisher.

[3] ASTM D3276. (2000). Standard Guide for Painting Inspectors (Metal Substrates). New York: American Society for Testing and Materials. 
[4] American Bureau of Shipping (ABS). (2007). Guidance Notes on The Inspection, Maintenance and Application of Marine Coating Systems, Third Edition. United States: ABS.

[5] Salbino, S. (2013). Buku Pintar Gadget Android untuk Pemula. Lembar Langit Indonesia. 